ISSN 1999-4907

www.mdpi.com/journal/forests

Article

\title{
Landscape Transformation in Tropical Latin America: Assessing Trends and Policy Implications for REDD+
}

\section{Pablo Pacheco ${ }^{1, *}$, Mariel Aguilar-Støen ${ }^{2}$, Jan Börner ${ }^{3}$, Andres Etter ${ }^{4}$, Louis Putzel ${ }^{1}$ and Maria del Carmen Vera Diaz ${ }^{5}$}

1 Center for International Forestry Research (CIFOR), Jalan CIFOR Situ Gede, Bogor Barat 16115, Indonesia; E-Mail: 1.putzel@cgiar.org

2 Centre for Development and the Environment, University of Oslo, Sognsveien 68, 0855 Oslo, Norway; E-Mail: m.c.a.stoen@sum.uio.no

3 CIFOR, Rua do Russel 450, Bairro Glória, CEP 22.210-010, Rio de Janeiro, Brazil; E-Mail: j.borner@cgiar.org

4 Pontificia Universidad Javeriana, Departamento de Ecología y Territorio, Transv. $4^{\circ}$ No. $42-00$, Bogotá, Colombia; E-Mail: aetter@javeriana.edu.co

5 Global Development and Environment Institute (GDAE), Tufts University, 44 Teele Avenue, Medford, MA 02155, USA; E-Mail: mariadelcarmenveradiaz@gmail.com

* Author to whom correspondence should be addressed; E-Mail: p.pacheco@cgiar.org; Tel.: +62-251-8622-622; Fax: +62-251-8622-100.

Received: 18 November 2010; in revised form: 18 December 2010 / Accepted: 18 December 2010 / Published: 27 December 2010

\begin{abstract}
Important transformations are underway in tropical landscapes in Latin America with implications for economic development and climate change. Landscape transformation is driven not only by national policies and markets, but also by global market dynamics associated with an increased role for transnational traders and investors. National and global trends affect a disparate number of social, political and economic interactions taking place at the local level, which ultimately shapes land-use and socio-economic change. This paper reviews five different trajectories of landscape change in tropical Latin America, and discusses their implications for development and conservation: (1) Market-driven growth of agribusiness; (2) expansion and modernization of traditional cattle ranching; (3) slow growth of peasant agriculture; (4) logging in production forest frontiers; and (5) resurgence of agro-extractive economies. Contrasting trade-offs between economic development and forest conservation emerge across these
\end{abstract}


landscapes, calling for nuanced policy responses to manage them in the context of climate change. This discussion sets the background to assess how reduction of emissions from deforestation and forest degradation and enhancing carbon stocks (REDD+) aims should be better aligned with current landscape trajectories and associated actors to better address climate-change mitigation in forest landscapes with effective and equitable outcomes.

Keywords: drivers; land-use change; landscapes; Latin America; REDD+

\section{Introduction}

Forests are recognized as biodiversity repositories and carbon stocks [1]. Tropical deforestation, however, contributes around $20 \%$ of anthropogenic greenhouse gas emissions [2]. Forests also play an important role in the climate system, helping to regulate atmospheric circulations in the tropics by absorbing energy and recycling rainfall [3]. To what extent these functions can be sustained given the combined pressures of deforestation and global climate change is subject to considerable debate; some future scenarios go so far as to predict a large-scale dieback of forests in some tropical areas [4,5]. This paper focuses on assessing main trends of landscape transformation taking place in the tropical and subtropical landscapes in Latin America, where forests cover about 11.1 million $\mathrm{km}^{2}$ and savannahs 3.3 million $\mathrm{km}^{2}$ comprising different types of vegetation, mainly moist forests, dry forest, and grasslands [6] (Figure 1). The region as a whole has the world's highest rates of forest loss, although a large portion of the forest conversion occurs in the Amazon basin [7].

About a fifth of the total rural population in Latin America draws on forest resources to support their livelihoods. Around 25 million people make a living in its tropical zones: 12 million occupy forestlands in Mexico, 10 million in Amazonia, and three million in Central America [8]. This population is heterogeneous, comprising indigenous agriculturalists and other local people, migrant colonist farmers and medium- to large-scale ranchers and farmers. A significant number of people are also engaged in processing, trade and provision of services around forest and non-forest activities in forest landscapes. The diverse economic activities developed near or in forest landscapes constitute important sources of local employment and income, and contribute to the broader economy through taxes [9].

Almost uniformly, significant agricultural development for fulfilling domestic consumption as well as growing exports has expanded in tropical forestlands at the expense of forest goods and services. The trade-off between development and conservation in tropical landscapes has been widely debated in the literature [10]. As the role of forests in climate-change mitigation has become ever more irrefutable, the trade-off debate has gained momentum. A number of perspectives on development-conservation trade-offs co-exist. Some argue that promoting intensive and large-scale agriculture could lead to greater economic growth, reduce deforestation and improve land-use efficiency [9], others argue that community-based forest resources management is an effective way to enhance the livelihoods of forest people and protect forests $[11,12]$, and some suggest that diversified production systems and land-use mosaics have positive impacts on smallholders' welfare $[13,14]$. There is no single definitive way to manage the trade-offs, and most of the above views complement each other. 
Figure 1. Tropical forests and savannahs in Latin America.

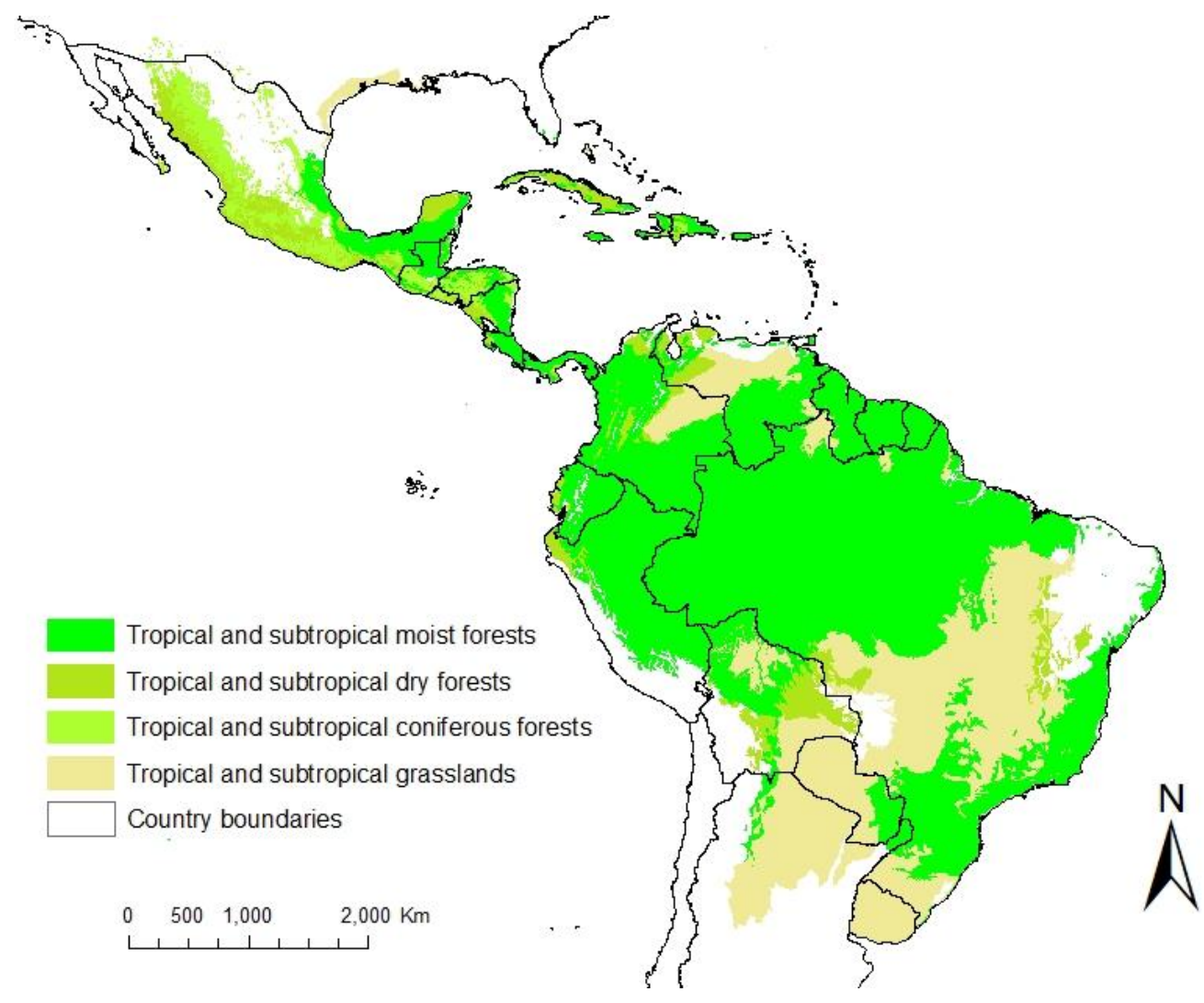

Authors' mapping of data from WWF [15].

This paper reviews the multiple trajectories taking place in a diversity of rural landscapes in tropical Latin America, which are associated to different social actors. It draws on a literature review and case studies at the landscape level to illustrate five contrasting socio-economic/actor contexts and related landscape outcomes: (1) Market-driven growth of agribusiness (medium- and large-scale farmers); (2) expansion and modernization of traditional cattle ranching (medium- and large-scale ranchers); (3) slow growth of peasant agriculture (smallholders); (4) logging in production forest frontiers (logging companies and small-scale loggers); and (5) resurgence of agro-extractive economies (indigenous people and traditional communities). We argue that differentiated conditions, development paths, and actors' behaviors need to be considered for successful implementation of reduction of emissions from deforestation and forest degradation, and enhancing carbon stocks (REDD+) in Latin America.

The paper is structured in six sections including this introduction. The next section provides a conceptual framework for analyzing the factors shaping landscape-level development pathways with implications for socio-economic and land-use transitions. The third section discusses the historical trends of rural change and their impacts on landscape transformation and deforestation. The fourth section introduces the case studies, and discusses the actor-landscape linkages and their implications for land-use, economic growth and human wellbeing. The fifth section compares the specific trade-offs in each landscape, as well as the challenges for addressing them under a potential REDD+ mechanism. The final section summarizes the main conclusions of this paper. 


\section{Making the Links: Actors and Landscape Transformation}

The debate about economic development and land use in Latin America's tropical forest landscapes has evolved around different perspectives regarding present and future trends. Some suggest that the main transformation taking place in tropical Latin America is related to demographic transition, with associated trends of migration and urbanization, as part of broader dynamics of rural and agrarian change [16]. In addition, some research highlights rural-urban migration as a process linked to international emigration and growing inflows of cash remittances that ultimately lead to reduced pressures on forestlands [17]. This view is questioned in a study by DeFries et al. [18] that found forest loss to be linked with urbanization and global trade. Others, from an economic perspective, observe that land and natural-resources use in the rural tropics, particularly in the Amazon region, has followed a boom-and-bust pattern, thereby rarely leading to economic growth and improved welfare [19]. In turn, ecologists argue that large-scale forest conversion combined with global climate change, could cause a gradual dieback of the Amazon forest through droughts and increased fire incidence [20].

We adopt an actor-focused approach in order to understand the different development paths that characterize landscape dynamics, acknowledging that production systems are linked to specific actor groups. We group actors in five categories. An important actor category in Latin American landscapes are indigenous people, most of whom maintain access to some common resources, and primarily depend on a combination of forest-based and agriculture economy, and while a majority is subsistence oriented, some are linked to markets and develop commercial activities. A second group is composed of traditional subsistence smallholders who are marginally connected to markets and sometimes depend on non-farm income streams. Often isolated from dynamic markets, a majority of these communities - along with the rural indigenous communities - continue to live in extreme poverty. A third group of small-scale farmers or peasants, some of which are migrant colonists, is characterized by diversified production systems including crop and livestock activities, with various degrees of specialization. In addition, a small percentage of actors are medium- and large-scale farmers and ranchers, who derive significant profits from already converted forestlands, and often have good access to national and global markets and financial resources. A last group comprises a heterogeneous group of independent loggers and logging companies. It should be mentioned that these actor categories overlap to various degrees and should not be conceived as distinct identity groups. Table 1 shows the main attributes of these categories with respect to their land-use objectives and land management. 
Table 1. Types of forest-based livelihoods and associated attributes of forest use.

\begin{tabular}{|c|c|c|c|c|c|}
\hline \multirow[b]{2}{*}{$\begin{array}{l}\text { Type of social } \\
\text { actor }\end{array}$} & \multicolumn{5}{|c|}{ Attributes linked to the type and objectives of land management } \\
\hline & $\begin{array}{c}\text { Land use } \\
\text { management }\end{array}$ & $\begin{array}{l}\text { Land-use } \\
\text { objectives }\end{array}$ & $\begin{array}{c}\text { Factors that } \\
\text { affect land-use } \\
\text { decisions }\end{array}$ & $\begin{array}{l}\text { Main type of } \\
\text { land use }\end{array}$ & $\begin{array}{c}\text { Forest income as } \\
\text { share of total } \\
\text { income of actor } \\
\text { group } \\
\end{array}$ \\
\hline Indigenous people & $\begin{array}{l}\text { Forest-based } \\
\text { activities and } \\
\text { shifting } \\
\text { agriculture }\end{array}$ & $\begin{array}{c}\text { Subsistence } \\
\text { oriented }\end{array}$ & $\begin{array}{l}\text { Availability of } \\
\text { resources and } \\
\text { labor }\end{array}$ & $\begin{array}{c}\text { Forest resources } \\
\text { extraction and } \\
\text { shifting } \\
\text { agriculture }\end{array}$ & High \\
\hline $\begin{array}{l}\text { Traditional } \\
\text { subsistence } \\
\text { smallholders }\end{array}$ & $\begin{array}{c}\text { Shifting } \\
\text { agriculture and } \\
\text { some forest } \\
\text { extraction }\end{array}$ & $\begin{array}{l}\text { Predominantly for } \\
\text { subsistence }\end{array}$ & $\begin{array}{l}\text { Family size and } \\
\text { availability of } \\
\text { labor, and other } \\
\text { productive assets }\end{array}$ & $\begin{array}{l}\text { Food production } \\
\text { in restored forest } \\
\text { fallows }\end{array}$ & Medium \\
\hline $\begin{array}{l}\text { Small-scale } \\
\text { farmers }\end{array}$ & $\begin{array}{l}\text { Small-scale } \\
\text { sedentary } \\
\text { agriculture }\end{array}$ & $\begin{array}{l}\text { Production for } \\
\text { subsistence and } \\
\text { cash income }\end{array}$ & $\begin{array}{l}\text { Access to labor, } \\
\text { and availability of } \\
\text { land, capital and } \\
\text { access to markets }\end{array}$ & $\begin{array}{c}\text { Mainly } \\
\text { agricultural } \\
\text { production under } \\
\text { diversified } \\
\text { systems }\end{array}$ & Medium to low \\
\hline $\begin{array}{l}\text { Large-scale } \\
\text { farmers and } \\
\text { ranchers }\end{array}$ & $\begin{array}{l}\text { Large-scale } \\
\text { agriculture }\end{array}$ & $\begin{array}{c}\text { Profit } \\
\text { maximization }\end{array}$ & $\begin{array}{l}\text { Access to land, } \\
\text { availability of } \\
\text { capital, non } \\
\text { family labor and } \\
\text { market access and } \\
\text { infrastructure }\end{array}$ & $\begin{array}{c}\text { Agricultural } \\
\text { production under } \\
\text { extensive or } \\
\text { intensive systems }\end{array}$ & Low to none \\
\hline $\begin{array}{l}\text { Loggers and } \\
\text { timber companies }\end{array}$ & $\begin{array}{l}\text { Logging could be } \\
\text { linked to } \\
\text { land-speculation } \\
\text { goals }\end{array}$ & $\begin{array}{c}\text { Profit } \\
\text { maximization }\end{array}$ & $\begin{array}{l}\text { Access to timber, } \\
\text { availability of } \\
\text { capital and access } \\
\text { to markets }\end{array}$ & $\begin{array}{l}\text { Selective logging } \\
\text { and marketing of } \\
\text { valuable timber } \\
\text { species }\end{array}$ & High \\
\hline
\end{tabular}

Changing policies and market environments have influenced the development of tropical forest landscapes in Latin America by shaping opportunities and constraints for social actors. Competing interests of social actors thus result in different land-use outcomes. We classify these landscapes into five types: (1) Areas dominated by large-scale agribusiness production units, where large forest areas have been replaced by agriculture; (2) areas where extensive ranching has homogenized landscapes by expanding pasture lands; (3) forest-agriculture mosaics, characterized by small-scale agricultural production units and scattered forests patches; (4) frontier and disputed areas, where forests are under pressure from competing interest groups, e.g., due to the presence of high-value timber resources; and (5) areas beyond the agricultural frontier with relatively large untouched forest areas. While conservation landscapes could represent a sixth distinct type of land use category, they are not included in our analysis since the focus of the current paper is on productive landscapes and the groups of producers and extractors associated with them. Table 2 shows the main features of these landscapes with regard to social actors, land tenure, and access to markets. 
Table 2. Characteristics of stylized landscapes in tropical Latin America.

\begin{tabular}{|c|c|c|c|c|}
\hline \multirow{2}{*}{ Type of landscape } & \multicolumn{4}{|c|}{ Attributes associated with the type of landscape } \\
\hline & Area with forest & Social actors & Land tenure & Access to markets \\
\hline $\begin{array}{l}\text { Agricultural lands } \\
\text { dominated by } \\
\text { agribusiness }\end{array}$ & Small & $\begin{array}{c}\text { Medium- and } \\
\text { large-scale farmers }\end{array}$ & Secure, clear rights & Good \\
\hline $\begin{array}{l}\text { Pasture lands } \\
\text { dominated by } \\
\text { extensive cattle } \\
\text { ranching }\end{array}$ & Small & $\begin{array}{c}\text { Medium- and } \\
\text { large-scale ranchers }\end{array}$ & $\begin{array}{c}\text { Relatively secure } \\
\text { rights }\end{array}$ & Relatively good \\
\hline $\begin{array}{l}\text { Forest-agriculture } \\
\text { mosaics under } \\
\text { diversified land uses }\end{array}$ & $\begin{array}{l}\text { Small to medium- } \\
\text { size forest areas } \\
\text { scattered in } \\
\text { agricultural lands, } \\
\text { but stable }\end{array}$ & $\begin{array}{c}\text { Peasants and migrant } \\
\text { colonists }\end{array}$ & $\begin{array}{l}\text { Secure, rights can be } \\
\text { relatively clear by de } \\
\text { facto regimes }\end{array}$ & Relatively good \\
\hline $\begin{array}{c}\text { Frontier areas with } \\
\text { dominance of logging }\end{array}$ & $\begin{array}{l}\text { Relatively large, but } \\
\text { decreasing }\end{array}$ & $\begin{array}{c}\text { Timber companies, } \\
\text { informal loggers and } \\
\text { migrant peasants }\end{array}$ & Insecure & Relatively poor \\
\hline $\begin{array}{l}\text { Areas beyond the } \\
\text { agricultural frontier } \\
\text { with local populations }\end{array}$ & $\begin{array}{l}\text { Large and relatively } \\
\text { stable }\end{array}$ & $\begin{array}{c}\text { Indigenous people and } \\
\text { other traditional } \\
\text { smallholders }\end{array}$ & $\begin{array}{c}\text { Insecure, though } \\
\text { progress in collective } \\
\text { titling }\end{array}$ & Poor \\
\hline
\end{tabular}

Source: Adapted from Chomitz [6].

Each landscape identified above, results from specific nature-society interactions, and represents a development path rooted in a specific historical context, which is understood here as a specific way in which natural, human and financial resources are used by actors with diverse social and economic goals. While in some cases these landscapes are easy to recognize because of their land-use and actor attributes, it is often difficult to draw boundaries since they are part of a continuum rather than defined types. It is noteworthy that landscapes change over time, as actors and land use compete with one another, such as between loggers and indigenous people, peasant forest-agriculture mosaics and grazing, or agribusiness development taking place over grazing lands. Describing land-use and actor competition is beyond the scope of this paper. Furthermore, different land-use trajectories evolve over time as a result of changing human intervention on the different landscapes. While deforestation from expanding agricultural land uses is by far the most important land-use change in the tropics in Latin America [21], trends of forest recovery have also been documented in the region [9,22].

At the risk of oversimplifying, the factors that define landscape type and development path are classified here as exogenous and endogenous, following Hecht [23] and Lambin and Meyfroidt [24]. Table 3 details the most significant exogenous and endogenous factors shaping landscape transformation. The most important external factors relate to (national and international) market conditions (e.g., volume of demand and amount of investments) and policy frameworks (e.g., taxes, fiscal incentives, public spending on infrastructure). The endogenous factors have to do with socio-economic interactions that take place in specific landscapes (i.e., acquisition and legitimization 
of land rights, technology adoption, development of value chains and power relationships). The interactions of these two sets of factors define outset, development path and landscape outcome.

Table 3. Factors shaping landscape transformation in tropical Latin America.

\begin{tabular}{|c|c|c|c|}
\hline \multirow{2}{*}{ Type of landscape } & \multicolumn{2}{|c|}{ Exogenous dynamics 'from outside' } & \multirow{2}{*}{$\begin{array}{c}\text { Endogenous processes 'from } \\
\text { inside' }\end{array}$} \\
\hline & Trade and investment & Public policies & \\
\hline $\begin{array}{l}\text { Agricultural lands } \\
\text { dominated by } \\
\text { agribusiness }\end{array}$ & $\begin{array}{l}\text { Increasing global demand of } \\
\text { agricultural commodities. } \\
\text { Large investment in processing } \\
\text { and storage facilities }\end{array}$ & $\begin{array}{l}\text { Roads improvement, } \\
\text { availability of cheap credit } \\
\text { and export incentives }\end{array}$ & $\begin{array}{c}\text { Development of vigorous } \\
\text { financial and market networks, } \\
\text { involving links with international } \\
\text { trade corporations }\end{array}$ \\
\hline $\begin{array}{l}\text { Pasture lands } \\
\text { dominated by } \\
\text { extensive cattle } \\
\text { ranching }\end{array}$ & $\begin{array}{l}\text { Increasing global consumption } \\
\text { of beef. Growing number of } \\
\text { slaughterhouses and meat- } \\
\text { packing plants }\end{array}$ & $\begin{array}{c}\text { Tax reduction and } \\
\text { availability of financial } \\
\text { incentives }\end{array}$ & $\begin{array}{c}\text { Adoption of improved pasture } \\
\text { and cattle management techniques }\end{array}$ \\
\hline $\begin{array}{l}\text { Forest-agriculture } \\
\text { mosaics under } \\
\text { diversified land uses }\end{array}$ & $\begin{array}{l}\text { Expansion of niche markets } \\
\text { often for perennial crops }\end{array}$ & $\begin{array}{c}\text { Reduced support for } \\
\text { colonization settlements, } \\
\text { although there is still some } \\
\text { land distribution }\end{array}$ & $\begin{array}{c}\text { Development of non-farm } \\
\text { economies, growing pressure on } \\
\text { land and emigration }\end{array}$ \\
\hline $\begin{array}{c}\text { Frontier areas with } \\
\text { dominance of logging }\end{array}$ & $\begin{array}{l}\text { Expansion of demand for } \\
\text { tropical timber, and growing } \\
\text { links with export markets }\end{array}$ & $\begin{array}{l}\text { Expansion of roads, } \\
\text { allocation of } \\
\text { concessionary rights in } \\
\text { some cases }\end{array}$ & $\begin{array}{l}\text { Extenuation of valuable timber } \\
\text { species due to the adoption of } \\
\text { selective logging operations }\end{array}$ \\
\hline $\begin{array}{l}\text { Areas beyond the } \\
\text { agricultural frontier } \\
\text { with local populations }\end{array}$ & $\begin{array}{l}\text { Limited but growing markets } \\
\text { for non-timber forest products }\end{array}$ & $\begin{array}{l}\text { Increasing recognition of } \\
\text { collective tenure rights, } \\
\text { mainly for indigenous and } \\
\text { other local people }\end{array}$ & $\begin{array}{l}\text { Growing social pressures for } \\
\text { recognition of tenure claims and } \\
\text { provision of social services }\end{array}$ \\
\hline
\end{tabular}

In Latin America, the role of exogenous factors in driving landscape change has become stronger over time, which is visible in the growing linkages with global markets of agricultural commodities and timber. This is mainly due to the existence of more developed value chains and increased processing capacity [25], growing investments in road infrastructure that have facilitated the access to forested lands [26], policy shifts related to the adoption of environmental regulations with implications for land use and forest management [27,28], and subsidies [29]. Public policies have also recognized tenure rights in favor of indigenous and other local people [12], and supported initiatives for land redistribution [30]. The endogenous processes in the region, depending on the landscape, are linked to the adoption of technologies and production systems, better developed value chains, increasing emigration and greater role of off-farm economies, and increasing claims for more secure land tenure.

Our analysis on landscape transformations, in the five types of landscapes identified above, is mainly based on the assessment of specific cases. This makes it difficult to determine the overall magnitudes to which they are expanding or shrinking in comparison to other landscapes types. That would require conducting an assessment of the landscape evolution throughout the whole region in at least two periods in time, a task which is beyond the scope of this paper. Nonetheless, in order to have some indicative information of the magnitude of these trends, Section 3 provides some aggregated information about some trends on which there is available information such as the magnitudes of forest 
loss and recovery, and main demographic dynamics. The latter analysis is complemented with a description of the main shifts in public policy implemented in the region in the last two decades.

\section{The Context: Trends in Rural Tropical Latin America}

\subsection{Crop Expansion, and Forest Loss and Recovery}

Arable and pasture lands have a higher growth in South America with respect to Mesoamerica (which is used in this paper to include all of Mexico and the seven countries in Central America). According to FAOSTAT data for the period 1990-2008, arable lands grew by 828 thousand ha $(0.15 \%$ per year) in Mesoamerica and 16.4 million ha (0.87\% per year) in South America. A closer assessment in Mesoamerica suggests that oil palm and sugarcane exhibited the highest annual growth rates in the period 1990-2008 (8.2\% and 1.7\%, respectively), followed by maize and cassava while land under cultivation for most other crops has tended to shrink. In South America, over the same period, high growth rates occurred for soybean, oil palm and sugarcane $(5.0 \%, 4.6 \%$ and $3.4 \%$, respectively), which are crops often planted in large-scale and capital-intensive production systems, while there were negative rates of growth for maize, rice, wheat, cassava and beans, which are crops largely associated with smallholder farming systems. In the same period, pasture lands decreased 2.7 million ha in Mesoamerica ( $-0.17 \%$ per year) and grew 11.3 million ha in South America (0.14\% per year) [31].

Deforestation rates for the period 1990-2005 were significant in both Mesoamerica and South America, equivalent to $0.71 \%$ and $0.47 \%$, but they have tended to decrease in the period 2005-2010. Magnitudes of deforestation are higher in the latter region [7]. Total annual deforestation for the region as a whole has shrunk from about 5 to 4 million ha between 2005 and 2010 [7]. Yet, in this same period, about 400 thousand ha of forests have been lost annually in Mesoamerica compared to about 3.5 million ha in South America (Table 4). It is noteworthy that FAO numbers comprise the total forest cover in the whole Latin America region, thus they also embrace temperate and dry forests, though they cover a smaller portion with respect to tropical forests. These data also mask the trends of growth in secondary forests which are particularly significant in Mesoamerica. In this regard, the forest transitions in Costa Rica, El Salvador, and the Pacific regions of Panama and Nicaragua are already well advanced [32], although this is less notorious in South America.

Table 4. Forest cover change in Latin America in selected periods.

\begin{tabular}{|c|c|c|c|c|c|c|c|}
\hline \multirow{3}{*}{ Region } & \multicolumn{3}{|c|}{ Forest area (thousand ha) } & \multicolumn{4}{|c|}{ Annual change in forest area } \\
\hline & \multirow[b]{2}{*}{1990} & \multirow[b]{2}{*}{2005} & \multirow[b]{2}{*}{2010} & \multicolumn{2}{|c|}{ 1990-2005 } & \multicolumn{2}{|c|}{ 2005-2010 } \\
\hline & & & & $\begin{array}{c}\text { thousand } \\
\text { ha/yr }\end{array}$ & $\%$ & $\begin{array}{c}\text { thousand } \\
\text { ha/yr }\end{array}$ & $\%$ \\
\hline Mesoamerica & 96,008 & 86,323 & 84,301 & -646 & -0.71 & -404 & -0.47 \\
\hline South America & 946,454 & 882,258 & 864,351 & $-4,280$ & -0.47 & $-3,581$ & -0.41 \\
\hline Total & $1,042,462$ & 968,581 & 948,652 & $-4,925$ & -0.49 & $-3,986$ & -0.42 \\
\hline
\end{tabular}

Source: Adapted by authors based on FAO [7].

Although biofuel feedstock (e.g., soybean bean and oil palm) are placing additional pressures on forest landscapes, mainly in the forest margins [33], expansion of pastures is still the main cause of 
deforestation in the region, since it explains more than two-thirds of deforestation in the Amazon region [34]. In this regard, decreasing deforestation rates in the Amazon could also be linked to a process of cattle ranching intensification, since cattle herds continue growing in tropical lands, and greater enforcement of environmental laws. In contrast, deforestation rates are still high in the Andean Amazon nations (e.g., Ecuador, Bolivia and Venezuela), and nothing suggests that they will decrease in the near future [35]. In turn, in Mesoamerica, the reduction of deforestation is linked to several factors, among them the reduction of governmental support for agricultural colonization and cattle ranching and the increasing percentage of remaining forests located in protected areas and/or indigenous territories. In addition, the rapid out-migration from rural areas to cities and to the United States and the growth of off-farm rural employment has left fewer young men interested in clearing forest, and governments have increased their support for reforestation, conservation and forest management on private and community-owned lands [32]. Below we explore the issues related to demographic and policy changes in the region.

\subsection{Population, Migration and Urbanization}

Since the 1970s, Latin America has experienced a demographic transition, with comparatively larger growth in urban population, of which an important contributing factor has been the high rate of rural to urban migration [16]. The proportion of rural population with respect to the total population, in both Mesoamerica and South America, is decreasing rapidly (Table 5). By 2008, the rural population in Mesoamerica represented about $29 \%$ of the total, compared to only $17 \%$ in South America. However, in absolute terms, the rural population is still growing in Mesoamerica, despite significant out-migration flows to the United States. Interestingly, this has led to an important role of cash remittances in supporting local rural economies [36]. In contrast, the rural population tends to decrease in South America, mainly as a result of a more rapid urbanization, and greater migration from the rural areas to the cities, except in Bolivia, Paraguay, Peru and Colombia [16]. Furthermore, there is some population still migrating to the rural tropical lands in the latter countries, and additionally in Brazil. Unfortunately, there is no aggregated data available for the region about rural-rural migration.

Table 5. Rural population change in Latin America.

\begin{tabular}{|c|c|c|c|c|c|c|c|}
\hline \multirow[t]{2}{*}{ Region } & \multicolumn{2}{|c|}{$\begin{array}{l}\text { Rural population } \\
\quad \text { (millions) }\end{array}$} & \multirow{2}{*}{$\begin{array}{c}\text { Rural } \\
\text { population } \\
\text { change (\%) } \\
1990-2008\end{array}$} & \multicolumn{2}{|c|}{$\begin{array}{c}\text { Rural } \\
\text { population/total } \\
\text { population }(\%)\end{array}$} & \multicolumn{2}{|c|}{$\begin{array}{c}\text { Rural } \\
\text { population/Total } \\
\text { arable land (\%) (b) }\end{array}$} \\
\hline & 1990 & 2008 & & 1990 & 2008 & 1990 & 2008 \\
\hline Mesoamerica & 39 & 43 & 0.5 & 35.1 & 28.9 & 1.3 & 1.4 \\
\hline South America & 75 & 66 & -0.8 & 25.5 & 17.0 & 0.8 & 0.6 \\
\hline Total & 114 & 109 & -0.3 & 28.1 & 20.3 & 0.9 & 0.8 \\
\hline
\end{tabular}

Note: (a) constitutes the annual growth rate in percents,

(b) refers to the total rural population divided by ha of arable land.

Source: Adapted by authors based on FAO [7]

Rural population growth in Mesoamerica also leads to relatively higher rural population densities with respect to total arable land (1.4\% in 2008) due to reduced availability of arable land. In contrast, 
rural population densities are relatively low in South America (0.6\% in 2008), due to the relatively large availability of land for cultivation. The higher rural population densities in Central America suggest a relative larger importance of smallholders in the rural landscapes, while the lower densities in South America, may be explained by the importance acquired by extensive cattle ranching, which requires reduced amounts of wage labor, and a greater expansion of medium- and large-scale agriculture. However, it is also important to mention that the highly skewed land distribution in Latin America has resulted in the concentration of large tracts of land held in some few hands. [37].

\subsection{Diverging Policies for Development and Conservation}

There is an increasing tension in the public policies applied by the governments in the region. As we discuss below, on the one hand, some policies attempt to facilitate economic growth in tropical landscapes linked to the promotion of the agribusiness sector, along with higher investments in infrastructure development, while on the other hand, policies to place forests under conservation are being implemented along with attempts to recognize tenure rights of indigenous and other local people, and enforce environmental laws. The former aims to promote the expansion of a more competitive agriculture linked to export markets, while the latter tends to protect forests and local people's livelihoods based on forest resources use. These policies have strong implications on shaping actors and land-use competition on the landscapes.

While most Latin American countries implemented import substitution policies in the 1960s and 1970s that fostered the expansion of large-scale agriculture, they also fostered agrarian reform which prompted the occupation of forest landscapes by smallholders [38]. In the mid- to late-1980s, many governments adopted structural adjustment policies to promote economic growth [39]. As a result, they have largely changed the region's economies from being closed and state dominated to being market oriented and more integrated into the world economy, particularly through cross-border flows of trade, investment, financial capital and technology [40]. In addition, these policies sought to create the institutional conditions for market forces to re-allocate land and resources, thus additional efforts to improve land administration were supported [41,42], which gradually embraced forestlands as well [43]. Over the mid-1980s, most Latin American countries returned to democracy, which coincided with increased concerns about the environment, and growing awareness of the territorial rights of indigenous people [44]. The latter has resulted in the recognition of tenure rights of indigenous people and other traditional populations over an area embracing about 200 million ha [45].

A growing international demand for grain began to take place in the early 2000s, notably from certain emerging economies (e.g., China), and greater integration of the agricultural sector in global markets [9], with increased involvement of transnational companies [46]. The latter prompted the expansion of soybean and beef production, with some of that growth taking place to the detriment of forests $[47,48]$. In similar ways, domestic demand for energy crops has expanded the production of biofuel feedstocks (i.e., soybean, sugar and oil palm) as a result of blending targets of biofuel with fossil fuels, particularly in Brazil, Argentina and Colombia [49]. Smallholders, with the exception of those engaged in perennial crop production (e.g., coffee, cocoa), have been less favored by global markets. In some places in the Andean-Amazon countries (i.e., Colombia, Bolivia and Peru) global demand has also stimulated some expansion of coca production into forest lands [50,51]. 
Latin American governments continue actively to expand transport infrastructure to link production zones with export seaports. These large-scale infrastructure projects are related to the 'Initiative for the Integration of Regional Infrastructure in South America' (IIRSA) program launched in 2000. This public spending has encouraged investments in processing and storage facilities for soybean, and also in biodiesel and meat-packing plants and slaughterhouses. In Central America and Mexico, there has also been increased support to the integration of the region through the development of transportation and electricity networks under the 'Plan Puebla-Panama'.

From the mid-1990s, governments in the region began to implement policies to halt the potential consequences of deforestation on biodiversity and climate change, in part due to increased interest from donors. Main actions involved the classification of forestlands as protected areas, conflicting in many cases with local populations' interests [52]. In Latin America, protected areas comprise about $25 \%$ of the land territory [53]. The creation of protected areas was accompanied by the formulation of land-use zoning plans as a way to manage the expansion of agricultural lands on vulnerable forest or biodiversity-rich ecosystems, with various degrees of success [54]. At the same time, many countries reviewed their forestry regulations and adopted new rules to promote longer-term sustainable management in national production forests [43]. Some countries, such as Costa Rica and Mexico, are implementing 'Payment for Environmental Services' (PES) mechanisms, to provide financial incentives to local actors who provide, or contribute to maintain, an 'environmental service' [55]. The outcomes of these initiatives have been analyzed elsewhere [56-58].

\section{Disparate Outcomes across Diverging Landscapes}

The trends mentioned above suggest that shifting, and often contradictory policy goals, along with long-term demographic transitions, have influenced forest loss and recovery in tropical Latin America. Yet these aggregated trends have different outcomes across the landscapes, depending on a diverse number of factors introduced in Section 2. This section analyses the specific nature-society interactions taking place in the five types of landscapes introduced earlier. Since there are no statistical data available on agriculture and forest management at the landscape level as well as on land-use transitions and resultant ecological impacts, and no disaggregation by actor, this section only offers a broad analysis of trends by type of landscape, and resultant social, economic and land-use effects, which are summarized in Table 6, according to the main five landscapes identified in Section 2.

As mentioned, agribusiness development often leads to higher deforestation rates, but contributes to significant economic growth and tends to concentrate income in a few medium- and large-scale landholders. Cattle ranching also leads to higher deforestation due to the predominance of extensive production systems, which require large amounts of land and create few jobs. Peasant agriculture tends to create jobs and generate local income and often leads to more complex land-use mosaics, which in some cases may lead to widespread deforestation depending on population density or demand for specific crops. Indigenous territories protect local livelihoods, but generate few economic benefits and are often located far from markets and social infrastructure. Finally, public production forests are often allocated under concessionary rights, which tend to do less harm to the forests, but concentrate incomes towards a few people, and do not guarantee forest conservation in the long run. 
As mentioned earlier, these landscapes are not static, since there is intense competition between actors who are variably favored by global factors and national policies. This competition is also the result of structural conditions in frontier landscapes, which are associated with land tenure insecurity, uneven market powers, and differentiated access to economic and institutional incentives. A more detailed description of each of these five situations is provided below. Each of the sub-sections below provides a description of some basic features distinguishing these landscapes (e.g., location, type of producers, dynamics of economic growth), a discussion of main both exogenous and endogenous factors shaping landscape change, and the principal social, economic and ecological outcomes.

Table 6. Major outcomes from land use in the different landscape types.

\begin{tabular}{|c|c|c|c|c|}
\hline \multirow[b]{2}{*}{ Type of landscape } & \multicolumn{4}{|c|}{ Outcomes associated with the type of landscape } \\
\hline & Pressure on forests & Economic growth & $\begin{array}{c}\text { Distribution of } \\
\text { benefits }\end{array}$ & $\begin{array}{l}\text { Access to } \\
\text { services }\end{array}$ \\
\hline $\begin{array}{l}\text { Agricultural lands } \\
\text { dominated by } \\
\text { agribusiness }\end{array}$ & $\begin{array}{c}\text { High, but often take } \\
\text { over already } \\
\text { deforested lands }\end{array}$ & $\begin{array}{l}\text { Relatively high, } \\
\text { mainly in soybean } \\
\text { frontiers }\end{array}$ & $\begin{array}{l}\text { Income concentrated } \\
\text { in few landholders }\end{array}$ & $\begin{array}{c}\text { Good, improving with } \\
\text { expansion of } \\
\text { infrastructure }\end{array}$ \\
\hline $\begin{array}{l}\text { Pasture lands } \\
\text { dominated by } \\
\text { extensive cattle } \\
\text { ranching }\end{array}$ & Often high & $\begin{array}{l}\text { Medium, but varies } \\
\text { depending on location } \\
\text { with respect to } \\
\text { markets }\end{array}$ & $\begin{array}{l}\text { Income largely } \\
\text { concentrated in } \\
\text { large-scale } \\
\text { landholders }\end{array}$ & Medium to good \\
\hline $\begin{array}{c}\text { Forest-agriculture } \\
\text { mosaics under } \\
\text { diversified land uses }\end{array}$ & $\begin{array}{l}\text { Varies from low in } \\
\text { some locales to high } \\
\text { in others }\end{array}$ & $\begin{array}{l}\text { Varies depending on } \\
\text { market conditions of } \\
\text { main crops produced }\end{array}$ & $\begin{array}{l}\text { More equal, but social } \\
\text { differentiation grows } \\
\text { over time }\end{array}$ & $\begin{array}{c}\text { Medium, but there are } \\
\text { large variations }\end{array}$ \\
\hline $\begin{array}{c}\text { Frontier areas with } \\
\text { dominance of logging }\end{array}$ & $\begin{array}{l}\text { Low, but tend to } \\
\text { grow linked to } \\
\text { market integration }\end{array}$ & $\begin{array}{l}\text { Large in forests with } \\
\text { valuable timber } \\
\text { species }\end{array}$ & $\begin{array}{l}\text { Benefits largely } \\
\text { concentrated in few } \\
\text { timber companies }\end{array}$ & Relatively poor \\
\hline $\begin{array}{l}\text { Areas beyond the } \\
\text { agricultural frontier } \\
\text { with local populations }\end{array}$ & Low & $\begin{array}{l}\text { Low, often timber } \\
\text { tends to be the main } \\
\text { source of cash income }\end{array}$ & $\begin{array}{c}\text { Benefits from } \\
\text { economic activities } \\
\text { are more equally } \\
\text { distributed }\end{array}$ & Poor \\
\hline
\end{tabular}

\subsection{Market-Driven Growth of Agribusiness Landscapes}

Development of large-scale intensive agriculture is not new in Latin America, but it is currently growing to an unprecedented scale in savannahs and tropical forestlands, where there is a relative abundance of land suitable for mechanized agriculture [9]. The epicenter of this expansion is in the State of Mato Grosso, Brazil, although soybean expansion has also taken place in lowland Bolivia, northwest Argentina and Paraguay [59,60]. In Mato Grosso, soybean production boosted from three million to 17 million tons between 1990 and 2008, at a growth rate of $25 \%$ per year [61]. The landholding size averages approximately 500 ha in Mato Grosso, though some plantations reach up to 10,000 ha [62]. This agro-industrial production model requires large amounts of chemical fertilizers and pesticides to raise productivity, and only a few skilled laborers. Farmers start the soybean chain in Mato Grosso. After the harvest, most of the soybeans are bought, collected and transported to crushing plants, or exported by the global soybean traders (i.e., ADM, Bunge and Cargill) or the largest 
Brazilian soybean company (Grupo André Maggi). These companies finance about $60-65 \%$ of the soybean area cultivated in Mato Grosso. Soybean growers often make forward sales (at planting time) to these trading companies in return for seed, fertilizer and chemicals [63,64]. This modus operandi gives the companies indirect control over large amounts of land and production.

Growing world demand for soybean, particularly from Europe and China, has been the main factor encouraging the expansion of soybean production in the region. This has increased the government's interest in promoting the agri-business sector, mainly in Brazil, where the government made large investments in road improvement and associated infrastructure to develop the soybean value chain (e.g., ports, waterways, and hydroelectric power) [26], which stimulated the arrival of international trading groups interested in expanding storage and processing facilities in the production zones. Furthermore, Brazilian investors were relatively active in expanding the soybean frontier in the Bolivian lowlands in eastern Santa Cruz, where the best agricultural lands are located [65], and in the Chaco region in northern Paraguay [66]. Some other factors that propelled this expansion were related to the relatively low land prices, particularly in the new agricultural frontiers in the forest margins, and to the availability of cultivars suited to the Cerrado soils developed in Brazil [67].

In Mato Grosso, benefits from expanded soybean production include increased export earnings and productivity (GDP per capita), since soybean constitutes a highly profitable agricultural crop. Social costs include land concentration, illegal land acquisition, and income concentration in a few medium- and large-scale landholders [68] and, in some cases, displacement of local populations [69]. The most important environmental cost of soybean expansion in Mato Grosso is the conversion of Amazon forest and Cerrado savannah, with associated effects on biodiversity loss and carbon emissions [70]. Soybean production leads to deforestation by two routes. First, soybean cultivation expands onto productive lands that were previously cleared for pasture, which forces cattle production deeper into the forest. Second, market conditions may favor soybean production, in which case soybean production 'leap-frogs' into areas of primary forest, in advance of ranching. Morton et al. [71] estimated that $13-23 \%$ of deforestation (by area) in Mato Grosso was for direct conversion to cropland in 2002 and 2003. Besides the deforestation on primary forest, the rapid conversion of the Cerrado savannah to soybean plantings constitutes a significant threat to this biome [72].

\subsection{Expansion and Modernization of Traditional Ranching}

Cattle ranching is widely practiced in tropical Latin America in the context of cheap land availability and labor scarcity, thus justifying frontier land occupation. Medium and large-scale traditional cattle ranching dominates in many landscapes in the Brazilian Amazon (e.g., southern Para, northern Mato Grosso and Rondônia, and in the south of Amazon state), and there is a gradual adoption of semi-intensive production systems in those areas better connected to infrastructure where land becomes scarcer such as in southern Para and the Trans-Amazon in Brazil $[73,74]$. The expansion of cattle-ranching activities is also a common feature in the rural lands in Andean-Amazon countries and Mesoamerica. For example, more than $70 \%$ of rural land of Colombia located in former forestlands is devoted to cattle grazing [75]. Although cattle ranching in Colombia has not historically received direct subsidies as much as in Brazil, it has often been a means to control large properties and evade taxes. Due to the costs of clearing the land, this is generally done by frontier colonists who then 
sell the cleared land to cattle ranchers [76]. In Bolivia, ranching is expanding in the Chiquitania, and is still linked to land speculation since pasture is the best way to justify land ownership.

The factors that make cattle ranching attractive are its lower risks compared to other agricultural activities, little use of purchased inputs, low costs of production, and banking services [77,78]. While the main beef markets are domestic, global beef markets began to play a major role at the turn of the millennium, particularly in Brazil, where more strict control of foot-and-mouth disease (FMD) improved the beef industry's access to international markets [47,79]. The explosive growth of the cattle population in Brazil has been accompanied by the expansion of the cattle industry, traditionally located in the southeast and centre-west regions of the country [80], to southern Para and Mato Grosso, matching the increase in cattle population, which has led to reducing the transportation costs, and increasing the competitiveness of traditional cattle ranchers [47]. Changes in beef supply from live cattle to packed meat have enabled industrial producers to reach more distant markets in the south and northeast of Brazil [81]. Growing beef exports from southern Brazil created a gap in the domestic market, which was (and is) filled by beef originated in the Amazon [82]. The presence of the meat industry has stimulated the arrival of investors from other regions interested in acquiring land, which increases the value of the land in the production zones, and thus fosters intensification [73].

One of the most obvious environmental effects of cattle ranching expansion in the tropics in Latin America is that it is the main source of deforestation, mainly since it is practiced under extensive and low production systems [79]. Although the economic profits that can be obtained from cattle ranching are relatively low, particularly when compared to other agricultural land uses, they are high enough to promote forest conversion [34]. For example, cattle ranching accounts for about $70 \%$ of total forest conversion in the Brazilian Amazon [34]. Furthermore, extensive cattle ranching systems tend to lead to a large land concentration in a handful of people, which also foster income concentration, and employs a small number of rural workers for herd management [83-85]. Yet in some old frontiers, the cattle economy is slowly increasing its productivity due to the adoption of more semi-intensified production systems related to the improvement of transport and processing infrastructure [73].

\subsection{Slow Growth of Peasant Agriculture}

Vigorous small-scale agriculture has evolved in the rural tropics in Latin America, although it is facing a slow growth, which in some landscapes is close to stagnation. Peasant agriculture embraces a diverse group of smallholders with production systems ranging from shifting cultivation, to more stable agricultural systems mixing annual (e.g., rice, cassava, maize) and perennial crops (e.g., coffee, cocoa), and livestock production, though in some cases more specialized systems have been implemented [86-88]. While smallholder agriculture has largely stabilized in many old colonization areas (e.g., Bragantina and Transamazon in Para, Rondônia, and northern Santa Cruz in Bolivia), it is still expanding in new frontier lands (e.g., Bolivia's northern Santa Cruz, Peru's Madre de Dios and Ucayali regions, Colombia's Caquetá and Guaviare departments, and Ecuador's Sucumbíos), often mirrored by greater deforestation rates. Given a greater articulation of small-scale farming with the market, its growth or stagnation is linked to market oscillations and smallholders' ability to compete with agribusiness expansion, though in some cases it is related to the trends in demand for some illicit 
crops (e.g., coca). Furthermore, expansion of colonization is also strongly linked to rural-rural immigration which is still taking place in spite of a dominant trend of rural-urban migrations.

In South America, the evolution of peasant agriculture is strongly linked to the colonization policies from the 1960s to the 1980s [89]. In many cases, however, failure of directed colonization, which resulted in relatively high turnover rates, facilitated the arrival of spontaneous colonists [90,91]. While in some cases smallholders in frontier lands tended to be displaced by large-holders [92]. In Central America, peasant agriculture was to some extent favored by historical (in Mexico and Guatemala) and contemporary (El Salvador) land reforms, which secured land ownership for smallholders. As mentioned earlier, public policies have reduced the support to colonization over time, and smallholders have often been discriminated against by liberalization policies that have tended to favor the development of tradable agricultural goods in a context of growing global markets [39]. Nonetheless, farm households over time become net buyers of food, and thus depend more on international food prices [93].

In Mesoamerica, in areas favorable for coffee cultivation, small-scale producers adopted shade coffee production on their farms. The peasant production system allowed for combining the production of this cash crop with food production in areas with relatively good market access [94], and organic coffee certification schemes [95,96] linked to increased local organization [97] are common. In the Brazilian Amazon, there has been a more gradual adoption of perennial crops (e.g., coffee, black pepper and cacao), particularly in Bragantina and along the Trans-Amazon highway in the State of Para, and in Rondônia [98,99]; cocoa production constitutes the main income stream of colonists settled in Yungas, La Paz.. Nevertheless, in areas not favorable for perennials there is gradual adoption of cattle raising mainly due to the fact that it constitutes a secure source of cash flow $[74,85]$. In other contexts, the slow markets for smallholders' crop production has led farmers to expand the production of illicit crops, particularly coca leaves in Colombia, Peru and Bolivia [50,100].

There is not a definitive balance regarding the outcomes of land occupation by smallholders in the tropics since their benefits depend on a diverse range of production systems. Yet it is clear that farmers dedicated to perennial crops are better off, and have higher land-use opportunity costs, than farmers who rely more on temporal crops, although this only depends on their opportunities to intensify their production [101], and access to other assets (e.g., human, financial) [88,102]. With regard to impacts of smallholder agriculture on deforestation, there is evidence that indicates that traditional agriculture has little impact on deforestation and leads to relatively diversified land-use mosaics while adoption of livestock production tends to fuel forest conversion [103]. In turn, some observers note that areas with peasant coffee production have experienced reforestation as a consequence of the way in which the production is organized in the landscape $[17,104]$.

\subsection{Large-Scale Commercial Logging on Public Lands}

The system of forest concessions is still active in some countries with available public production forest, such as Peru and Bolivia, and lately in Guatemala and Brazil. In Peru since the implementation of a new Forest Law in 2002, over seven million ha of production forest have been assigned to logging concessions [105]. In Bolivia, five million ha were granted in 1996 [106], which declined to 3.2 million ha in 2010. In Guatemala, only 500 thousand ha in the Petén region are under concessionary 
rights to communities. In turn, Brazil has beginning to grant some public forests as concessions in the Amazon basin after a process of tenure-rights clarification. Concession logging has been promoted by national natural resource or forestry authorities - often with the support of multinational conservation institutions - as a means to promote sustainable management of national production forests, generate national revenues, and prevent clear-cutting. However, to a large degree, concession logging has not been able to spatially and temporally reorganize logging according to the prescribed zoning and management planning. Since illegal logging is still taking place in zones designated for sustainable forest management, concessions cannot ensure forest regeneration of valuable species, and thus the concession system is not an adequate mechanism to prevent post-logging conversion.

For example, in Peru, some researchers have claimed to see evidence in satellite images that the new concession system is 'protecting the Amazon' [107]. However, others have found that in the years following implementation of concessions, indiscriminate logging practices continued much as before for a number of reasons, including: The exclusion of smaller logging companies from the concession system, which favors larger companies with greater capital; the selling of concession documents to 'legalize' illegally logged timber by concessionaires who conduct little if any logging on their own concessions; and a thriving informal market for several rare hardwood timber species destined for export to China, the new major source of demand for Peruvian timber [108]. In addition, in the long term forest concessions do not prevent post-logging conversion by agricultural migrants to a mosaic of agricultural fields and pastures, regenerating swiddens and secondary forest [109,110]. The latter is due not only to the small investments of concessionaries to prevent encroachment of production forests, but also to the lack of mechanisms and support from the public agencies to enforce existing forestry rights.

In addition, lack of infrastructural development limits the potential for concession logging to change patterns of extraction in the logging frontier in Peru. The majority of concession land is located on the forest frontier far from transportation infrastructures [105]. It can be argued that the failure of the government to take transport into account when locating the new forest concessions ensures that extractors of timber continue to extract from existing roadsides and riversides, from where they cut the most basic logging roads, thereby increasing the porosity of the forest frontier to expansion of unorganized groups of agricultural migrants. In Bolivia, the problems facing the concession system are not much different. While it was expected that concession loggers would diversify the number of species exploited, timber companies holding concessionary rights have only logged the most valuable species, which in more distant areas tend to perpetuate the system of selective logging which dominated in the past. Furthermore, in Bolivia, concessions face the challenge of relatively reduced rates of natural regeneration which could put future harvesting at risk [111].

\subsection{Resurgence of Traditional Agro-Extractive Economies}

As mentioned earlier, the 1980s and 1990s witnessed the emergence of growing indigenous claims for the formal recognition of their land tenure rights in the statutory law. These claims were accompanied by demands from traditional populations, whose livelihoods were based on the harvesting of non-timber forest resources, to obtain secure access rights to the forestlands they traditionally occupied, such as the movement of rubber tappers in Acre, in the Brazilian Amazon [112]. 
While the indigenous claims led to the formal recognition of collective ownership rights of the indigenous people over the lands that they occupied, under different tenure modalities (e.g., indigenous territories or community lands) [44] the demands from agro-extractive populations led to the creation of the 'extractive reserves', which would further evolve into several models (e.g., agro-extractive reserves, sustainable development reserves, and agro-extractive settlements) [12].

Regionally, this process of forest tenure reform has contributed to reshape forest landscapes to the extent that it has reinforced the rights of local populations, increasing their capacity to resist encroachment from third parties and enhancing their opportunities to benefit from their land and forest resources [12]. The populations favored by the tenure reforms include a diversity of indigenous groups and traditional populations who depend on non-timber forest resources to a high degree to make a living, but also depend on shifting cultivation. Timber extraction tends to grow where indigenous and collective lands are relatively close to infrastructure, rivers and roads. Many indigenous communities have created timber enterprises and begun to make deals with loggers, but due to legal and institutional barriers and lack of bargaining power have led them to capture only a small portion of the benefits [113]. There are some important exceptions, since community groups that received some external support and resources were able to obtain significant incomes from their forests resources (e.g., Cururú in Guarayos, Bolivia, and Layasiksa in the RAAN, Nicaragua) [12]. Only in a few cases, however, do communities benefit from access to international forest markets, such as in the case of agro-extractive communities linked to international Brazil nut markets [114].

The rights to land have often been granted under collective tenure regimes, although in practice access to land embraces both collective and family-based arrangements. While in some cases access to common forestlands is mediated through strong local norms, in others cases, social norms are relatively weak and tenure is relatively fragmented. For example, in Bolivia, several indigenous groups do not have a solid organization at the level of the territory, and people have access to land and forest resources through extended family groups, which complicates coordination for governing the acquired lands [115]. In spite of that, some research has evidenced that indigenous territories are relatively well protected, and tend to reduce the pressures on forest conversion, such as in Brazil [116].

\section{Discussion: Implications for REDD+ Implementation}

This section explores what the likely implications for REDD+ implementation in the different types of landscapes discussed would be. It is beyond the scope of this paper to explain the characteristics of REDD+ which have been described elsewhere [117]. REDD+ implemented through national governments becomes a plausible future scenario for tropical Latin America. However, the diversity of actor and landscape represents a significant challenge for the design of effective and equitable REDD+ interventions, which are two main features to be considered on REDD+ design [117]. The current debate on the architecture of REDD+ has yet to answer many open questions such as how to balance efficiency and equity under compensation schemes, and what the beneficiaries and practices to be rewarded will be, among others [118]. A main message of this paper is that no 'one-size-fits-all' approach to REDD+ could possibly deliver both cost-effectiveness and equity performance measures when diverse actors shape landscapes and development pathways in multiple and complex ways. 
Some additional issues, which have been mentioned in Section 4 are particularly important for REDD+ implementation, these are: Pressure on forests, opportunity costs, tenure and resource access, poverty and wellbeing, and governance conditions. Table 7 summarizes these different issues, showing that there are important differences across landscapes since, for example, landholders linked to agribusiness have higher land-use opportunity costs, compared with cattle ranchers or indigenous people, whose opportunity costs are relatively low. Furthermore, the former tend to concentrate relatively large tracts of land under conditions which are relatively secure, while insecure rights dominate in forest frontiers and often smallholders and indigenous people lack of formal rights to their lands. With respect to wellbeing, there are significant gaps between the highly capitalized landholders engaged in agribusiness, and the indigenous groups, with a larger diversity among smallholders. Finally, governance conditions tend to improve in landscapes with longer-term human occupation processes, in which there is a larger presence of the state and/or more stable customary norms, while higher conflict and disputes over resources still dominate in the forest frontier landscapes.

Table 7. Landscape types and key REDD+ design issues.

\begin{tabular}{|c|c|c|c|c|c|}
\hline \multirow[b]{2}{*}{ Type of landscape } & \multicolumn{5}{|c|}{ Key characteristics with relevance for REDD+ design } \\
\hline & $\begin{array}{l}\text { Pressure on } \\
\text { forests }\end{array}$ & $\begin{array}{l}\text { Opportunity } \\
\text { costs }\end{array}$ & $\begin{array}{c}\text { Tenure and resource } \\
\text { access }\end{array}$ & $\begin{array}{l}\text { Poverty/ } \\
\text { wellbeing }\end{array}$ & $\begin{array}{c}\text { Governance } \\
\text { conditions }\end{array}$ \\
\hline $\begin{array}{l}\text { Agricultural lands } \\
\text { dominated by } \\
\text { agribusiness }\end{array}$ & High & High & $\begin{array}{c}\text { Relatively clear } \\
\text { ownership often in a } \\
\text { context of little } \\
\text { developed land } \\
\text { administration systems }\end{array}$ & $\begin{array}{l}\text { Almost generally } \\
\text { capitalized and } \\
\text { comparatively well } \\
\text { off }\end{array}$ & $\begin{array}{l}\text { Often farmers are } \\
\text { well organized and } \\
\text { are politically } \\
\text { influential }\end{array}$ \\
\hline $\begin{array}{l}\text { Pasture lands } \\
\text { dominated by } \\
\text { extensive cattle } \\
\text { ranching }\end{array}$ & High & Low & $\begin{array}{l}\text { Not formal ownership } \\
\text { rights but tenure tend } \\
\text { to be secure, although } \\
\text { in some cases claims } \\
\text { are shaky (land } \\
\text { grabbing) }\end{array}$ & $\begin{array}{l}\text { Some capitalized } \\
\text { ranchers, but often } \\
\text { medium-income } \\
\text { levels }\end{array}$ & $\begin{array}{l}\text { Often persist land } \\
\text { disputes, but local } \\
\text { elites control local } \\
\text { decision-making } \\
\text { and are politically } \\
\text { influential }\end{array}$ \\
\hline $\begin{array}{l}\text { Forest-agriculture } \\
\text { mosaics under } \\
\text { diversified land } \\
\text { uses }\end{array}$ & $\begin{array}{l}\text { Medium to } \\
\text { high }\end{array}$ & $\begin{array}{l}\text { Low to } \\
\text { medium }\end{array}$ & $\begin{array}{l}\text { Often no formal land } \\
\text { ownership but tenure } \\
\text { relatively secure }\end{array}$ & $\begin{array}{l}\text { Both poor and } \\
\text { comparatively } \\
\text { wealthy groups }\end{array}$ & $\begin{array}{c}\text { Strong local } \\
\text { organizations in } \\
\text { some regions, but } \\
\text { often no voice }\end{array}$ \\
\hline $\begin{array}{c}\text { Frontier areas with } \\
\text { dominance of } \\
\text { logging }\end{array}$ & $\begin{array}{c}\text { Low (but } \\
\text { impacts on } \\
\text { degradation) }\end{array}$ & $\begin{array}{l}\text { Medium to } \\
\text { high }\end{array}$ & $\begin{array}{l}\text { Formal sector often } \\
\text { engaged in } \\
\text { concessions, but large } \\
\text { informal (often illegal) } \\
\text { sector }\end{array}$ & $\begin{array}{l}\text { Capitalized timber } \\
\text { companies, but } \\
\text { poor people linked } \\
\text { to the informal } \\
\text { sector }\end{array}$ & $\begin{array}{l}\text { Often disputes on } \\
\text { forest access, and } \\
\text { influential local } \\
\text { elites }\end{array}$ \\
\hline $\begin{array}{l}\text { Areas beyond the } \\
\text { agricultural frontier } \\
\text { with local } \\
\text { populations }\end{array}$ & Low & Low & $\begin{array}{l}\text { Community use and } \\
\text { access rights often } \\
\text { well defined, but not } \\
\text { always secure }\end{array}$ & $\begin{array}{c}\text { Widespread } \\
\text { poverty. Little or } \\
\text { no access to public } \\
\text { services (few } \\
\text { exceptions) }\end{array}$ & $\begin{array}{l}\text { Local groups } \\
\text { sometimes well } \\
\text { organized, but } \\
\text { often no voice }\end{array}$ \\
\hline
\end{tabular}


The REDD+ design challenges that arise from the issues raised in this paper can be summarized as follows: (1) Identifying and targeting key actors and landscapes for REDD+ incentives; (2) designing the optimal incentive mix to change the behavior of these actors, e.g., depending on their livelihood strategies and opportunity costs; (3) embedding REDD+ interventions in existing institutional systems and overcoming governance deficits; and (4) assuring participation and benefit capture among poor stakeholders. National policy makers dispose of only a limited set of intervention options to directly influence land use decisions in forest landscapes, especially when donor commitments depend on short-term performance indicators. Many national REDD+ strategies will thus have to rely heavily on incentive and disincentive-based policy instruments, such as conditional compensation transfers and improved enforcement of forest use and access regulations through command-and-control measures (e.g., regulations, permits, control systems and sanctions). We suggest here that the strategies have to be tailored, however, according to the landscape type and defined objectives. Other conditions to take into account are related to institutional capacities and legal environments, which differ greatly from country to country, although looking into those conditions is beyond the scope of this paper.

Making the right decisions on the first of the four design challenges (targeting) will clearly determine the extent to which REDD+ can become an effective climate change mitigation measure. Targeting landscapes with dynamic forest cover change would thus seem a natural starting point for pilot action. Economic (opportunity costs) and institutional (tenure regulation and security) conditions will not, however, always be favorable for the effective delivery of REDD+ incentives on the ground. In some areas opportunity costs may be simply too high for conservation payments to represent an attractive alternative, such as in the case of agribusiness landscapes, while compensations could be an attractive options for actors with low land-use opportunity costs such as cattle ranchers or indigenous people [105]. Furthermore, poorly regulated and insecure tenure, common features on forest frontiers, also frequently hamper the enforcement of conservation regulations or render conditional compensation payments ineffective, e.g., when multiple land users claim ownership or cannot guarantee the protection of forests. As a result, decision makers face tradeoffs between the potential additionality and the feasibility of targeting early REDD+ action to forest frontiers. In addition, there are cases, such as indigenous territories which have been able to acquire formal tenure rights and enforce such rights where forest conservation could be rewarded but with little effects on additionality. Even more, the scale of interventions must go beyond frontier landscapes to minimize leakage into current low pressure forest areas and consolidate land use dynamics in agricultural mosaics. In this case, REDD+ could actively stimulate changes of land-use strategies in smallholder landscapes.

One of the key implications of landscapes being transformed by diverse, sometimes poor, actors with varying resource strategies is that REDD+ policies will have diverse impacts on rural livelihoods (second design challenge). This has led to substantial speculation about how incentives and disincentives should be used to achieve REDD+ goals among potential target groups, with different opinions on which group should be favored [119]. While it is clear that land-asset distribution and deforestation patterns will determine how incentives and disincentives of a given REDD+ policy mix play out in terms of benefit distribution, and thus co-benefits on poverty alleviation, the lack of consensus as to what represents an equitable distribution of rewards or punishment probably represents the single most important obstacle for REDD+ at the national level [119]. While a command-andcontrol dominated REDD+ strategy tends to disproportionately hurt those who have benefited from 
deforestation in the past, such as cattle ranchers and smallholder colonists actively converting forest to agricultural land uses, the same actors would become the prime beneficiaries of a compensation-based REDD+ approach [109], but the effects in practice will depend on how substantial such payments are.

In Brazil, for example, a history of uncoordinated colonization, illegal land grabbing and conflicting land claims represent a shaky basis for compensation payments to large-scale producers, but excluding them per se from compensation would appear politically unfeasible since many of these actors have legitimate rights on land, though they have led to significant land concentration, which in many cases have been driven by goals of land speculation. The distribution of land among actors and their contribution to deforestation, nonetheless, vary considerably across countries. While in the Brazilian Amazon, about $80 \%$ of deforestation is caused by large-scale landholders (on landscapes dominated by agribusiness and cattle ranching), smallholders (in forest-agriculture mosaics) dominate deforestation patterns in the Peruvian and Colombian Amazon [109,110,120]. In Bolivia, about $70 \%$ of deforestation is caused by large-scale soybean producers and ranchers [60]. While command-and-control measures for law enforcement can play an active role in contributing to reduce deforestation, these actors will likely demand a reward to compensate the foregone benefits of not converting forests to agricultural land uses, mainly in the context of a growing demand for their production.

In addition, smallholders at remote forest margins - generally poor by standard poverty measuresoften have few land-use alternatives to traditional high-emission slash-and-burn cultivation. Without improved access to alternative technologies and income opportunities, command-and-control measures to halt deforestation could drive some farmers further into poverty, whereas conditional compensation-based REDD+ bears the risk of creating dependencies on external income streams as traditional extensive land use strategies have to be abandoned. Even a careful balance of compensation incentives and command-and-control disincentives may therefore prove insufficient to induce a low-carbon transformation of the rural economy. Enablement through improved public services, market access and technical assistance as well as the need to regulate and spatially delimit land tenure on a large scale may thus add substantially to the cost of REDD+ implementation in practice (third design challenge).

Rewards to forest stewards with a good track record, such as indigenous and traditional populations may increase the perceived fairness of REDD+, but tend to reduce cost-effectiveness as funds would be diverted from high deforestation areas (fourth design challenge). This is one of the major trade-offs faced by REDD+ implementers. Ultimately, the success of REDD+ will depend on the ability of recipient countries' governments to negotiate a fair deal with all land users [121]. Widespread de facto tolerance of illegal forest cover change, over many years, probably requires subsidizing the compliance of large players to some extent. Rewards to good forest stewards may thus also become a political imperative, despite their potential to reduce leakage and encourage local efforts to protect indigenous lands from external invasion. Political bargaining power and strategies, however, vary considerably across actor groups. While some smallholders are represented by strong multi-level organizations, indigenous groups are also well organized in politically influential umbrella organizations, traditional population groups, such as extractivists, often lack the means to influence the national policy debate. Participation and equal benefit sharing will thus also depend on the ability of NGO and grassroots organizations to effectively involve their clients in the development of national REDD+ strategies. 
REDD+ is, after all, the challenge of becoming serious about forest conservation. The international debate has doubtless helped to raise political awareness and perhaps political will in developing countries. The risk remains that REDD+ funding will simply be misused as an instrument to buy political support under weak governance structures. Whether this occurs or not will ultimately depend on international REDD+ transfers being truly conditional and substantial enough for recipient countries to give up opportunistic behavior in favor of a serious change of course on the ground.

\section{Conclusions}

This paper reviews the diversity of land-use transitions linked to diverse trends of landscape development in rural tropical Latin America. We review evidence showing that development paths in tropical landscapes, and resulting land-use and socio-economic situations, are highly heterogeneous, and depend strongly on the actors involved and interactions between global markets with national policies, and the resulting local responses across the different situations. This makes effectiveness of policy responses more difficult. Each situation manifests different development and conservation trade-offs. There are contrasting outcomes between agribusiness landscapes, where greater economic growth takes place at the cost of forest conversion and economic gains are concentrated towards a few large-scale landholders and corporations, and landscapes where indigenous and traditional populations tend to prevail, but have few choices to improve their living conditions. Landscapes dominated by smallholders often result in more income opportunities reflected in more complex land-use mosaics.

Significant variations apply, however, depending on the stage of frontier development and there is a growing interaction with global and local factors shaping landscape change. Global markets are having a growing influence in shaping agribusiness development in the tropics, bringing significant development to agribusiness landscapes but at the expense of forest conservation, and often leading to land concentration, and with limited income distribution. In turn, states have been more active in formalizing tenure rights, particularly for indigenous and other traditional people, thus helping them to protect their domestic economies and secure long-term forest conservation, but there is little chance tenure reforms alone will lift them out of poverty. Furthermore, traditional cattle ranching is still the most widespread but least environmentally desirable land use, and its growth is increasingly being driven by market forces rather than state incentives, which make its expansion more difficult to manage. Finally, sustainable forest management is still a goal that is hard to achieve in the rural tropics.

REDD+ may have an important role in influencing which development paths will tend to prevail in tropical landscapes - with aims linked to avoidance of deforestation, sustainable forest management or conservation. Yet many hard choices have to be made for REDD+ to work in practice, mainly to balance cost-effectiveness and equity, and to create the institutional conditions for achieving the expected outputs. Due to the diversity of situations discussed here, it is reasonable to assume that a 'one-size-fits-all' approach will not work in REDD+ implementation. In some countries, targeting deforestation hotspots at the forest frontier may be feasible only after conflicting land claims have been settled and well delimited. While some REDD+ action must be well targeted, national strategies must remain inclusive and allow for benefits and costs being shared across stakeholders according to politically feasible fairness criteria. REDD+ thus goes far beyond the compensation of land users' opportunity costs in high pressure areas and requires addressing some of the underlying structural 
reasons for resource overuse and underdevelopment in tropical forest areas. The costs of REDD+ may have been widely underestimated by the early proponents. The potential benefits, however, may go far beyond climate change mitigation. The latter will hinge on whether there is sufficient political will to take the development of the world's forest margins seriously, and involve the diverse populations who depend on forest resources, so to provide new opportunities for them to enhance their well being.

\section{References and Notes}

1. Gibbs, H.K.; Brown, S.; Niles, J.O.; Foley, J.A. Monitoring and estimating tropical forest carbon stocks: making REDD a reality. Environ. Res. Lett. 2007, 2, 1-13.

2. $\quad$ van der Werf, G.R.; Morton, D.C.; DeFries, R.S.; Olivier, J.G.J.; Kasibhatla, P.S.; Jackson, R.B.; Collatz, G.J.; Randerson, J.T. $\mathrm{CO}_{2}$ emissions from forest loss. Nat. Geosci. 2009, 2, 737-738.

3. Cox, P.M.; Harris, P.P.; Huntingford, C.; Betts, R.A.; Collins, M.; Jones, C.D.; Jup, T.E.; Marengo, J.A.; Nobre, C.A. Increasing risk of Amazonian drought due to decreasing aerosol pollution. Nature 2008, 453, 212-216.

4. Laurance, W.F.; Lovejoy, T.E.; Vasconcelos, H.L.; Bruna, E.M.; Didham, R.K.; Stouffer, P.C.; Gascon, C.; Bierregaard, R.O.; Laurance, S.G.; Sampaio, E. Ecosystem Decay of Amazonian Forest Fragments: a 22-Year Investigation. Conserv. Biol. 2002, 16, 605-618.

5. Cox, P.M.; Betts, R.A.; Collins, M.; Harris, P.P.; Huntingford, C.; Jones, C.D. Amazonian forest dieback under climate-carbon cycle projections for the 21st century. Theor. Appl.Climatol. 2004, 78, 137-156.

6. Chomitz, K. Overview at Loggerheads? Agricultural Expansion, Poverty Reduction, and Environment in the Tropical Forests; The World Bank: Washington, DC, USA, 2007.

7. FAO. Global Forest Resources Assessment 2010; Food and Agriculture Organization of the United Nations: Rome, Italy, 2010.

8. Kaimowitz, D. Pobreza y Bosques en América Latina: Una Agenda de Acción. Revista Forestal Centroamericana 2003, 39-40, 13-15.

9. Grau, H.R.; Aide, M. Globalization and land-use transitions in Latin America. Ecol. Soc. 2008, $13,16$.

10. Lee, D.R.; Barrett, C.B. Tradeoffs or Synergies? Agricultural Intensification, Economic Development and the Environment; CAB International Publishing: New York, NY, USA, 2001.

11. Bray, D.B.; Merino-Pérez, L.; Barry, D. The Community Forests of Mexico: Managing for Sustainable Landscapes; University of Texas Press: Austin, TX, USA, 2005.

12. Larson, A.M.; Cronkleton, P.; Barry, D.; Pacheco, P. Tenure Rights and Beyond: Community Access to Forest Resources in Latin America; CIFOR: Bogor, Indonesia, 2008.

13. Barham, B.L.; Coomes, O.T.; Takasaki, Y. Rain forest livelihoods: income generation, household wealth and forest use. Unasylva 1999, 50, 34-42.

14. Browder, J.O.; Pedlowski, M.; Summers, P.M. Land use patterns in the Brazilian Amazon: Comparative farm-level evidence from Rondônia. Hum. Ecol. 2004, 32, 197-224.

15. WWF. Ecoregions profile. Available online: http://www.worldwildlife.org/science/ecoregions/ (accessed on 9 August 2010). 
16. Carr, D.L.; Lopez, A.C.; Bilsborrow, R.E. The population, agriculture and environment nexus in Latin America: country-level evidence from the latter half of the twentieth century. Popul. Environ. 2009, 30, 222-246.

17. Hecht, S.B.; Kandel, S.; Gomes, I.; Cuellar, N.; Rosa, H. Globalization, forest resurgence, and environmental politics in El Salvador. World Dev. 2006, 34, 308-323.

18. DeFries, R.S.; Rudel, T.; Uriarte, M.; Hansen, M. Deforestation driven by urban population growth and agricultural trade in the twenty-first century. Nature Geosci. 2010, 3, 178-181.

19. Rodrigues, A.S.L.; Ewers, R.M.; Parry, L.; Souza Jr, C.; Verissimo, A.; Balmford, A. Boom-and-bust development patterns across the Amazon deforestation frontier. Science 2009, 324, 1435-1437.

20. Nepstad, D.C.; Stickler, C.M.; Soares-Filho, B.; Merry, F. Interactions among Amazon land use, forests and climate: Prospects for a near-term forest tipping point. Philos. T. R. Soc. B. 2008, 363, 1737-1746.

21. Lambin, E.F.; Geist, H.J. Regional Differences in Tropical Deforestation. Environment 2003, 45, 22-36.

22. Uriarte, M.; Schneider, L.; Rudel, T.K. Land transitions in the tropics: Going beyond the case studies. Biotropica 2010, 42, 1-2.

23. Hecht, S. The new rurality: Globalization, peasants and the paradoxes of landscapes. Land Use Policy 2010, 27, 161-169.

24. Lambin, E.F.; Meyfroidt, P. Land use transitions: Socio-ecological feedback versus socio-economic change. Land Use Policy 2010, 27, 108-118.

25. UNCTAD. World Investment Report 2009: Transnational Corporations, Agricultural Production and Development; United Nations Conference on Trade and Development: New York, NY, USA, 2009.

26. Killeen, T. A Perfect Storm in the Amazon Wilderness: Development and Conservation in the Context of the Initiative for the Integration of Regional Infrastructure of South America (IIRSA); Conservation International: Washington, DC, USA, 2007.

27. Fearnside, P.M. Brazil's evolving proposal to control deforestation: Amazon still at risk. Environ. Conserv. 2009, 36, 177-179.

28. Nepstad, D.; Soares-Filho, B.S.; Merry, F.; Lima, A.; Moutinho, P.; Carter, J.; Bowman, M.; Cattaneo, A.; Rodrigues, H.; Schwartzman, S.; McGrath, D.G.; Stickler, C.M.; Lubowski, R.; Piris-Cabezas, P.; Rivera, S.; Alencar, A.; Almeida, O.; Stella, O. The end of deforestation in the Brazilian Amazon. Science 2009, 326, 1350-1351.

29. Hecht, S. Soybeans, development and conservation on the Amazon frontier. Dev. Change 2005, 36, 375-404.

30. Pacheco, P. Agrarian reform in the Brazilian Amazon: Its implications for land distribution and deforestation. World Dev. 2009, 37, 1337-1347.

31. FAOSTAT. Statistical database. Available online: http://faostat.fao.org/site/339/default.aspx (accessed on 8 July 2010).

32. Kaimowitz, D. The prospects for Reduced Emissions from Deforestation and Degradation (REDD) in Mesoamerica. Int. Forest. Rev. 2008, 10, 485-495. 
33. Lapola, D.M.; Schaldacha, R.; Alcamoa, J.; Bondeau, A.; Koch, J.; Koelking, C.; Priess, J.A. Indirect land-use changes can overcome carbon savings from biofuels in Brazil. P. Natl. Acad. Sci. USA 2010, 107, 3388-3393.

34. Margulis, S. Causes of Deforestation of the Brazilian Amazon; Report No. 22; World Bank: Washington, DC, USA, 2004; p. 107.

35. Killeen, T.J.; Guerra, A.; Calzada, M.; Correa, L.; Calderon, V.; Soria, L.; Quezada, B.; Steininger, M.K. Total historical land-use change in Eastern Bolivia: Who, where, when, and how much? Ecol. Soc. 2008, 13, 36.

36. Rigg, J. Land, farming, livelihoods and poverty: rethinking the links in the rural south. World Dev. 2006, 34, 180-202.

37. Quijandría, B.; Monares, A.; Ugarte, R. Assessment of Rural Poverty: Latin America and the Caribbean; IFAD: Santiago de Chile, Chile, 2001.

38. Kay, C. Rural Latin America: exclusionary and uneven agricultural development. In Capital, Power, and Inequality in Latin America; Halebsky, S., Harris, R.L., Eds.; Westview press: Boulder, CO, USA, 1995.

39. Gwynne, R.N.; Kay, C. Latin America Transformed: Globalization and Modernity; London \& Oxford University Press: New York, NY, USA, 2000.

40. Gwynne, R.N. Structural reform in South America and Mexico: Economic and regional perspectives. In Latin America Transformed: Globalization and Modernity; Gwynne, R.N.; Kay, C., Eds.; London \& Oxford University Press: New York, NY, USA, 2004.

41. Deininger, K. Land Policies for Growth and Poverty Reduction; World Bank: Washington, DC, USA, 2003.

42. Kay, C. Why East Asia overtook Latin America: Agrarian reform, industrialisation and development. Third World Q. 2002, 23, 1073-1102.

43. Pacheco, P.; Barry, D.; Cronkleton, P.; Larson, A. The Role of Informal Institutions in the Use of Forest Resources in Latin America; CIFOR: Bogor, Indonesia, 2008.

44. Roldan, R. Models for Recognizing Indigenous Land Rights in Latin America. World Bank Environment Department, World Bank: Washington, DC., USA, 2004.

45. Pacheco, P.; Barry, D.; Cronkleton, P.; Larson, A.; Monterroso, I. From agrarian to forest tenure reforms: Assessing their impacts in local people and forests. In The 12th Biennial Conference of the International Association for the Study of Commons, Cheltenham, UK, 14-18 July 2008.

46. Baker, M.M. Soy monoculture in the Americas: Globalization ruins food economy. EIR 2004, 45, 46-49.

47. Walker, R.; Browder, J.; Arima, E.; Simmons, C.; Pereira, R.; Caldas, M.; Shirota, R.; Zen, S. Ranching and the new global range: Amazonia in the 21st century. Geoforum 2009, 40, 732-745.

48. Nepstad, D.C.; Stickler, C.M.; Almeida, O.T. Globalization of the Amazon soy and beef industries: Opportunities for conservation. Conserv. Biol. 2006, 20, 1595-1603.

49. Arias, T.; Coelho, S.T.; Guardabassi, P.; Grisoli, R.; Flores, N.; James, C.S.; Manzanares, P.; Ballesteros, M.; Aroca, G.; Soler, L.; Villalón, G.; García, M.G.; Guerrero, G.; Riegelhaupt, E. Feedstock Production in Latin America. Biofuels Assessment on Technical Opportunities and Research Needs for Latin America; UNAM, CENBIO, INTA, CIEMAT, UCV: Morelia, Mexico, 2009. 
50. Bradley, A.V.; Millington, A.C. Coca and Colonists: Quantifying and Explaining Forest Clearance under Coca and Anti-Narcotics Policy Regimes. Ecol. Soc. 2008, 13, 31.

51. Etter, A.; McAlpine, C.; Phinn, S.; Pullar, D.; Possingham, H. Unplanned land clearing of Colombian rainforests: spreading like disease? Landscape Urban Plan. 2006, 77, 240-254.

52. Adams, W.M.; Aveling, R.; Brockington, D.; Dickson, B.; Elliott, J.; Hutton, J.; Roe, D.; Vira, B.; Wolmer, W. Biodiversity Conservation and the Eradication of Poverty. Science 2004, 306, 1146-1149.

53. Chape, S.; Blyth, S.; Fish, L.; Fox, P.; Spalding, M. United Nations List of Protected Areas; UNEP, WCMC, WCPA, UICN: Cambridge, UK, 2003.

54. Naughton-Treves, L.; Holland, M.B.; Brandon, K. The role of protected areas in conserving biodiversity and sustaining local livelihoods. Annu. Rev. Env. Resour. 2005, 30, 219-252.

55. Engel, S.; Pagiola, S.; Wunder, S. Designing payments for environmental services in theory and practice: an overview of the issues. Ecol. Econ. 2008, 65, 663-674.

56. Muñoz-Piña, C.; Guevara, A.; Torres, J.M.; Braña, J. Paying for the hydrological services of Mexico's forests: Analysis, negotiations and results. Ecol. Econ. 2008, 65, 725-736.

57. Pagiola, S. Payments for environmental services in Costa Rica. Ecol. Econ. 2008, 65, 713-725.

58. Wunder, S.; Engel, S.; Pagiola, S. Taking stock: A comparative analysis of payments for environmental services programs in developed and developing countries. Ecol. Econ. 2008, 65, 834-852.

59. Grau, H.R.; Gasparri, N.I.; Aide, T.M. Agriculture expansion and deforestation in seasonally dry forests of northwest Argentina. Environ. Conserv. 2005, 32, 140-148.

60. Pacheco, P. Agricultural expansion and deforestation in Lowland Bolivia: the import substitution versus the structural adjustment model. Land Use Policy 2006, 23, 205-225.

61. IBGE. Pesquisa Agricola Municipal 2009; Instituto Brasileiro de Geografia e Estatísticas: Rio de Janeiro, Brazil, 2010.

62. IBGE Censo Agropecuario 2006; Instituto Brasileiro de Geografia e Estatística: Rio de Janeiro, Brazil, 2008.

63. Cadier, C. Estudo da Dinâmica da Cadeia da Soja no Mato Grosso: Estrutura, Funcionamento e Perspectivas de Sustentabilidade; Master thesis; Escola Internacional de Comércio e Desenvolvimento: Lyon, France, 2004.

64. Gasques, E. Desempenho e Crescimento do Agronegócio no Brasil; IPEA/DISET: Brasília, Brazil, 2003; p. 45.

65. Pacheco, P. Agricultural expansion and deforestation in Lowlands Bolivia: the import substitution versus the structural adjustment model. Land Use Policy 2006, 23, 205-225.

66. Riquelme, Q.; Semino, S.; Joensen, L. Paraguay sojero: Soy Expansion and Its Violent Attack on Local and Indigenous Communities in Paraguay; Grupo de Reflexion Rural: Buenos Aires, Argentina, 2006.

67. EMBRAPA SOJA Tecnologias de Produção de Soja - Região Central do Brasil 2009 e 2010; Embrapa Soja: Londrina, Brazil, 2008; p. 262.

68. Fearnside, P.M. Brazil's Cuiaba- Santarem (BR-163) Highway: The environmental cost of paving a soybean corridor through the Amazon. Environ. Manage. 2007, 39, 601-614. 
69. van Gelder, J.W.; Dros, J.M. From Rainforest to Chicken Breast: Effects of Soybean Cultivationf for Animal Feed on People and Nature in the Amazon Region-a Chain of Custody Study; Milieudefensie, Friends of the Earth Netherlands and Cordaid: Amsterdam, The Netherlands, 2005.

70. Galford, G.L.; Melillo, J.L.; Kicklighter, D.W.; Cronin, T.W.; Cerri, C.E.P.; Mustard, J.F.; Cerri, C.C. Estimating greenhouse gas emissions from land-cover and land-use change: Future scenarios of deforestation and agricultural management. P. Natl. Acad. Sci. USA 2010, doi:10.1073/pnas.1000780107.

71. Morton, D.C.; De Fries, R.S.; Shimabukuro, Y.E.; Anderson, L.O.; Arai, E.; Del Bon Espirito-Santo, F.; Freitas, R.; Morisette, J. Cropland expansion changes deforestation dynamics in the southern Brazilian Amazon. P. Natl. Acad. Sci. USA 2006, 103, 14637-14641.

72. Grunwald, M. The Clean Energy Scam. Time Magazine, March 27 2008. Available online: http://www.time.com/time/magazine/article/0,9171,1725975-1,00.html (accessed on 15 July 2010).

73. Pacheco, P. Agrarian change, cattle ranching and deforestation: Assessing their linkages in southern Para. Environ. Hist. 2009, 15, 493-520.

74. Walker, R.; Moran, E.; Anselin, L. Deforestation and cattle ranching in the Brazilian Amazon: External capital and household processes. World Dev. 2000, 28, 683-699.

75. Etter, A.; McAlpine, C.; Possingham, H. A historical analysis of the spatial and temporal drivers of landscape change in Colombia since 1500. Ann. Assoc. Am. Geogr. 2008, 98, 1-27.

76. Legrand, C. Colonización y protesta campesina en Colombia (1850-1950). Universidad Nacional de Colombia: Bogotá, Indonesia, 1988.

77. Hecht, S. Valuing land uses in Amazonia: Colonist agriculture, cattle and petty expansion in comparative perspective. In Conservation of Neotropical Forests: Working from Traditional Resource Use; Redford, K.H., Padoch, C., Eds.; Columbia University Press: New York, NY, USA, 1992.

78. Kaimowitz, D. Livestock and Deforestation in Central America in the 1980s and 1990s: A Policy Perspective; EPTD Discussion Paper No. 9; International Food Policy Research Institute, Interamerican Institute for Cooperation on Agriculture: Washington, DC, USA, 1995.

79. McAlpine, C.A.; Etter, A.; Fearnside, P.M.; Seabrook, L.; Laurance, W.F. Increasing world consumption of beef as a driver of regional and global change: A call for policy action based on evidence from Queensland (Australia), Colombia and Brazil. Global Environ. Chang. 2009, 19, 21-33.

80. Silva, C.A.B.; Batalha, M.O. Estudo sobre a eficiência econômica e competitividade da cadeia agroindustrial da pecuária de corte no Brasil; FUNARBE: Brasilia, Brazil, 1999; p. 226.

81. Poccard-Chapuis, R. Les reseaux de la conquete filiere bovine et structuration de l'espace sur les fronts pionniers d'Amazonie Oriental Bresilienne; Universite de Paris $\mathrm{X}-$ Nanterre: Paris, France, 2004.

82. Kaimowitz, D.; Mertens, B.; Wunder, S.; Pacheco, P. Hamburger Connection Fuels Amazon Destruction: Cattle Ranching and Deforestation in Brazil's Amazon; Center for International Forestry Research (CIFOR): Bogor, Indonesia, 2004; p. 9. 
83. Faminow, M.D. The Brazilian cattle sector: Status, prospects and controversies. Can. J. Agr. Econ. 1997, 45, 179-199.

84. Faminow, M.D. Cattle, Deforestation, and Development in the Amazon: An Economic, Agronomic, and Environmental Perspective; CAB International: Wallingford, UK and New York, NY, USA, 1998; p. 253.

85. da Veiga, J.B.; Tourrand, J.F.; Piketty, M.G.; Poccard-Chapuis, R.; Alves, A.M.; Thales, M.C. Expansão e Trajetórias da Pecuária na Amazônia; Editora UNB: Brasilia, Brazil, 2004; p. 161.

86. Perz, S.G.; Walker, R. Household life cycles and secondary forest cover among small farm colonists in the Amazon. World Dev. 2002, 30, 1009-1027.

87. Pichón, F.; Marquette, C.; Murphy, L.; Bilsborrow, R. Choice and constraints in the making of the Amazon frontier: settler, land-use decisions and environmental change in Ecuador. In Patterns and Processes of Land Use and Forest Change in the Amazon; Wood, C., Porro, R., Eds.; University of Florida Press: Gainesville, FL, USA, 2003.

88. Walker, R.; Perz, R.; Caldas, M.; Silva, L.T. Land-use and land-cover change in forest frontiers: The role of household life cycles. Int. Regional Sci. Rev. 2002, 25, 169-199.

89. Nelson, M. El aprovechamiento de las tierras tropicales en América Latina; Siglo XXI: Mexico DF, Mexico, 1977.

90. Rudel, T.K.; Horowitz, B. Tropical Deforestation: Small Farmers and Land Clearing in the Ecuadorian Amazon; Columbia University Press: New York, NY, USA, 1993; p. 234.

91. Moran, E.F. Colonization in the Transamazon and Rondônia. In Frontier Expansion in Amazonia; Schmink, M., Wood, C.H., Eds.; University of Florida Press: Gainesville, FL, USA, 1984; pp. 285-303.

92. Schmink, M.; Wood, C.H. Contested Frontiers in Amazonia; Columbia University Press: New York, NY, USA, 1992.

93. de Janvry, A.; Sadoulet, E. The global food crisis and guatemala: What crisis and for whom? World Dev. 2010, 38, 1328-1339.

94. Ponette-González, A.G. 2001: a household analysis of Huastec Maya agriculture and land use at the height of the coffee crisis. Hum. Ecol. 2007, 35, 289-301.

95. Bray, D.B.; Plaza-Sánchez, J.L.; Contreras-Murphy. E. Social dimensions of organic coffee production in Mexico: Lessons for eco-labeling initiatives. Soc. Natur. Resour. 2002, 15, 429-446.

96. Jaffee, D. Brewing Justice: Fair Trade Coffee, Sustainability and Survival; University of California Press: Berkeley, CA, USA, 2007.

97. Eakin, H.; Tucker, C.; Castellanos, E. Responding to the coffee crisis: a pilot study of farmers' adaptations in Mexico, Guatemala and Honduras. Geogr. J. 2006, 172, 156-171.

98. Börner, J.; Mendoza, A.; Vosti, S.A. Ecosystem services, agriculture, and rural poverty in the Eastern Brazilian Amazon: Interrelationships and policy prescriptions. Ecol. Econ. 2007, 64, 356-373.

99. Rodriguez-Medel, J.G. The Environmental and Human Dimensions of Frontier Expansion in the Transamazon Highway Colonization Area; University of León: Madrid, Spain, 2009. 
100. Etter, A.; McAlpine, C.; Phinn, S.; Pullar, D.; Possingham, H. Characterizing a tropical deforestation front: a dynamic spatial analysis of a deforestation hotspot in the Colombian Amazon. Global Change Biol. 2006, 12, 1409-1420.

101. Vosti, S.; Witcover, J.; Carpentier, C.L. Agricultural Intensification by Smallholders in the Western Brazilian Amazon: From Deforestation to Sustainable Land Use; International Food Policy Research Institute: Washington, DC, USA, 2003.

102. Takasaki, Y.; Barham, B.L.; Coomes, O.T. Wealth Accumulation and Activity Choice Evolution among Amazonian Forest Peasant Households; Staff Paper Series 434; University of Wisconsin-Madison, Department of Agricultural and Applied Economics: Madison, WI, USA, 2000.

103. Pacheco, P. Smallholder livelihoods, wealth and deforestation in the Eastern Amazon. Hum. Ecol. 2009, 37, 27-41.

104. Redo, D.; Bass, J.O.J.; Millington, A. Forest dynamics and the importance of place in western Honduras. Appl. Geogr. 2009, 29, 91-110.

105. Salo, M.; Toivonen, T. Tropical Timber Rush in Peruvian Amazonia: Spatial Allocation of Forest Concessions in an Uninventoried Frontier. Environ. Manag. 2009, 44, 609-623.

106. Pacheco, P. Estilos de desarrollo, deforestación y degradación de los bosques en las tierras bajas de Bolivia; CEDLA, TIERRA, CIFOR: La Paz, Bolivia, 1998; p. 389.

107. Oliveira, P.J.C.; Asner, G.P.; Knapp, D.E.; Almeyda, A.; Galván-Gildemeister, R.; Keene, S.; Raybin, R.F.; Smith, R.C. Land-Use Allocation Protects the Peruvian Amazon. Science 2007, 317, 1233-1236.

108. Putzel, L. Upside-down: Global Forestry Politics Reverses Direction of Ownership in Peru-China Timber Commodity Chains. In XIII World Forestry Congress, Buenos Aires, Argentina, 18-23 November 2009.

109. Börner, J.; Wunder, S.; Wertz-Kanounnikoff, S.; Tito, M.R.; Pereira, L.; Nascimento, N. Direct conservation payments in the Brazilian Amazon: Scope and equity implications. Ecol. Econ. 2010, 69, 1272-1282.

110. Armas, A.; Börner, J.; Tito, M.R.; Cubas, L.D.; Coral, S.T.; Wunder, S.; Reymond, L.; Nascimento, N. Pagos por Servicios Ambientales para la conservación de bosques en la Amazonía peruana: Un análisis de viabilidad; SERNANP: Lima, Peru, 2009.

111. Fredericksen, T.S.; Putz, F.E.; Pattie, P.; Pariona, W.; Peña-Claros, M. Sustainable forestry in Bolivia: Beyond planned logging. J. Forest. 2003, 101, 37-40.

112. Hecht, S.; Cockburn, A. The Fate of the Forest: Developers, Destroyers and Defenders of the Amazon; Verso: London, UK, 1989.

113. Pokorny, B.; Johnson, J. Community Forestry in the Amazon: The Unsolved Challenge of Forests and the Poor; Overseas Development Institute, ODI: London, UK, 2008.

114. Stoian, D. Variations and Dynamics of Extractive Economies: the Rural Urban Nexus of Non-Timber Forest Use in the Bolivian Amazon; $\mathrm{PhD}$ dissertation; University of Freiburg: Freiburg, Germany, 2000.

115. Cronkleton, P.; Pacheco, P.; Ibargüen, R.; Albornoz, M.A. Reformas en la tenencia forestal en Bolivia: La gestión comunal en las tierras bajas; CIFOR, CEDLA, RRI: La Paz, Bolivia, 2009. 
116. Nepstad, D.; Schwartzman, S.; Bamberger, B.; Santilli, M.; Ray, D.; Schlesinger, P.; Lefebvre, P.; Alencar, A.; Prinz, E.; Fiske, G.; Rolla, A. Inhibition of Amazon deforestation and fire by parks and indigenous lands. Conserv. Biol. 2006, 20, 65-73.

117. Angelsen, A. Moving Ahead with REDD: Issues, Options, and Implications. CIFOR: Bogor, Indonesia, 2008.

118. Wertz-Kanounnikoff, S.; Angelsen, A. Global and national REDD+ architecture: Linking institutions and actions. In Realising REDD+: National Strategy and Policy Options; Angelsen, A., Ed.; CIFOR: Bogor, Indonesia, 2009.

119. Ricketts, T.H.; Soares-Filho, B.; da Fonseca, G.A.B.; Nepstad, D.; Pfaff, A.; Petsonk, A.; Anderson, A.B.; Boucher, D.; Cattaneo, A.; Conte, M.; Creighton, K.; Linden, L.; maretti, C.; Moutinho, P.; Ullman, R.; Victurine, R. Indigenous lands, protected areas, and slowing climate change. Plos Biology 2010, 8, 1-4.

120. Etter, A.; McAlpine, C.; Phinn, S.; Pullar, D.; Possingham, H. Unplanned land clearing of Colombian rainforests: Spreading like disease? Landsc. Urban Plan. 2006, 77, 240-254.

121. Pascual, U.; Muradian, R.; Rodríguez, L.C.; Duraiappah, A. Exploring the links between equity and efficiency in payments for environmental services: A conceptual approach. Ecol. Econ. 2010, $69,1237-1244$.

(C) 2010 by the authors; licensee MDPI, Basel, Switzerland. This article is an open access article distributed under the terms and conditions of the Creative Commons Attribution license (http://creativecommons.org/licenses/by/3.0/). 